\title{
Dampak Pemberian Motivasi, Work Environment Serta Leadership Style Pada Peningkatan Kerja Karyawan PT. Gapura Angkasa Bandara Sultan Hasanuddin Makassar
}

\author{
Haeranah Alwany \\ STIE Nobel Makassar \\ Email: Rana090768@icloud.com
}

\begin{abstract}
The purpose of this research is to know the influence of giving motivation, work environment and leadership style on performance of employees At PT. Gapura Angkasa in Makassar Hasanuddin International Airport which consists of giving motivation, work environment and leadership style. The population in this case at 54 employees. Methods of data analysis using quantitative with linier regression. Based on a test of the free variabel $\mathrm{F}$ jointly have significant and positive influence against variabels bound performance. Through testing (R) correlation coefficient obtained that level of correlation or relationship between giving motivation, work environment and leadership style on performance of employees is a high relationship i.e. 60.8\%. And the ability to work is the most dominant factor influencing the performance of employees at PT. Angkasa Gate in Makassar Hasanuddin International Airport
\end{abstract}

Keywords: giving motivation, work environment, leadership style and performance

\section{Abstrak}

Tujuan dari penelitian ini adalah untuk mengetahui pengaruh gaya kepemimpinan, lingkungan kerja dan Motivasi kerja terhadap kinerja karyawan Pada PT. Gapura Angkasa di Bandara Internasional Hasanuddin Makassar yang terdiri dari memberikan motivasi, lingkungan kerja dan gaya kepemimpinan. Populasi dalam hal ini adalah 54 karyawan. Metode analisis data menggunakan kuantitatif dengan regresi linier. Berdasarkan uji variabel bebas $\mathrm{F}$ secara bersama-sama memiliki pengaruh signifikan dan positif terhadap kinerja variabel terikat. Melalui pengujian (R) koefisien korelasi diperoleh bahwa tingkat korelasi atau hubungan antara pemberian motivasi, lingkungan kerja dan gaya kepemimpinan terhadap kinerja karyawan adalah hubungan yang tinggi yaitu 60,8\%. Dan kemampuan untuk bekerja adalah faktor yang paling dominan mempengaruhi kinerja karyawan di PT. Gerbang Angkasa di Bandara Internasional Makassar Hasanuddin.

Kata kunci: pemberian motivasi, work environment, leadership style dan kinerja

\section{Pendahuluan}

Kinerja merupakan keberhasilan seorang karyawan dalam menjalankan tugas yang dibebankan kepadanya. Kinerja yang baik pada karyawan dapat dilihat dari kemampuan seorang karyawan dalam memahami dan menyelesaikan tugas yang diberikan kepadanya sehingga dalam bekerja ia mendapatkan hasil yang optimal termasuk juga pada PT. Gapura Angkasa di Bandara Internasional Sultan Hasanuddin Makassar. Kinerja merupakan hasil kerja yang dicapai seorang karyawan secara kualitas dan kuantitas dalam melaksanakan tugas sesuai dengan tanggung jawab yang diberikan kepadanya (Mangkunegara, 2005). Faktor penentu pencapaian kinerja dalam organisasi adalah faktor kemampuan dan faktor motivasi. Kemampuan maksudnya karyawan yang memiliki IQ di atas rata-rata dengan pendidikan yang memadai maka ia akan lebih mudah mencapai kinerja yang diharapkan.

Sebagai Lembaga Pelayanan Publik, PT. Gapura Angkasa di Bandara Internasional Sultan Hasanuddin Makassar haruslah memberikan pelayanan yang prima terhadap masyarakat, melalui pelayanan dan fasilitas yang sesuai dengan kaidah kaidah pelayanan jasa seperti melayani keberangkatan maupun kedatangan penumpang atau strategic marketing yang akan menarik dan meberikan kenyamanan bagi penumpang. Selain kualitas berita, 
kuantitas berita juga tidak mencapai persentase yang dibebankan kepada masing masing karyawan, sebagaimana terlihat pada tabel berikut ini:

Tabel 1. Capaian Kinerja Karyawan

\begin{tabular}{|c|c|c|c|c|}
\hline No & Indikator & $\begin{array}{c}\text { Target Kinerja } \\
\text { Karyawan/hari }\end{array}$ & Realisasi & Capaian \\
\hline 1 & Kuantitas pelayanan & $\begin{array}{c}2 \text { laporan } \\
1 \text { informasi }\end{array}$ & 1 laporan & $33,33 \%$ \\
\hline 2 & Kualitas pelayanan & Laporan terbaru & Laporan lama & $50,0 \%$ \\
\hline 3 & Marketing value & Tinggi & Rendah & $40,0 \%$ \\
\hline 4 & Nara sumber & Berkompeten & Kurang berkompeten & $40,0 \%$ \\
\hline 5 & Mencari narasumber & Turun kelapanagn & Melalui Telp kantor & $40,0 \%$ \\
\hline 6 & Wawancara & 2 wawancara & 1 paket wawancara & $40,0 \%$ \\
\hline
\end{tabular}

Sumber: PT. Gapura Angkasa di Bandara Internasional Sultan Hasanuddin Makassar 2019

Berdasarkan diatas tergambar bahwa kinerja karyawan PT. Gapura Angkasa di Bandara Internasional Sultan Hasanuddin Makassar belum sesuai dengan target yang diharapkan. Kuantitas berita yang seharusnya dikerjakan oleh seorang karyawan dengan target 2 laporan dan 1 berita perharinya, hanya dikerjakan 1 laporan saja, sehingga capaian kinerja hanya 33,3 persen. Untuk kualitas berita yang diharapkan juga tidak sesuai dengan capaian kinerja dimana para karyawan memproduksi berita terkini dengan persentase 50 persen saja sedangkan yang 50 persen lainnya merupakan laporan lama atau laporan yang diulang ulang sehingga tidak tercapai hasil kerja yang diinginkan.

Adapun fenomena-fenomena yang terjadi mengenai gaya kepemimpinan di lingkungan PT. Gapura Angkasa di Bandara Internasional Sultan Hasanuddin Makassar berdasarkan pengamatan penulis antara lain kurangnya pimpinan berkonsultasi dengan bawahan serta kurang menggunakan saran bawahan dalam mengambil keputusan. Kemudian pimpinan tidak selalu memberikan arahan kepada karyawan dalam menyelesaikan pekerjaan. Hal ini mengindikasikan pimpinan kurang intensif dalam memberikan pengarahan terhadap bawahan, tidak intensifnya pengarahan terhadap bawahan akan menurunkan motivasi dalam bekerja dan pada akhirnya berpengaruh pada kinerja yang tidak optimal. Di bagian pemberitaan PT. Gapura Angkasa di Bandara Internasional Sultan Hasanuddin Makassar yang memiliki 4 ruangan hanya tersedia 1 buah AC, Semestinya demi kenyamanan kerja semua ruangan terutama ruangan yang terdapat peralatan komputer haruslah dipasang AC sehingga komputer dapat lebih terawat, dan kondisi demikian menyebabkan penurunan semangat kerja reporter karena suasana ruangan yang dirasakan tidak nyaman.

Karyawan tidak menyelesaikan tugas dengan baik. Kondisi itu menggambarkan rendahnya motivasi karyawan PT. Gapura Angkasa di Bandara Internasional Sultan Hasanuddin Makassar dalam melaksanakan tupoksinya. Kemudian rendahnya disiplin karyawan dalam memenuhi jam kerja, hal ini menunjukkan rendahnya motivasi karyawan dalam mengerjakan kewajibannya sebagai karyawan PT. Gapura Angkasa di Bandara Internasional Sultan Hasanuddin Makassar. Selanjutnya Karyawan kurang memiliki improvisasi, inovasi dan kreatifitas dalam bekerja. Rendahnya krestifitas karyawan dan kurangnya improvisasi serta inovasi dalam bekerja menggambarkan rendahnya motivasi 
karyawan. Semestinya seorang karyawan harus mempunyai improvisasi, inovasi dan kreatifitas yang tinggi dalam bekerja sehingga kinerja yang dihasilkan menjadi berkualitas.

\section{Literature Review}

\subsection{Pengertian Manajemen Sumberdaya Manusia}

Manajemen memang dapat mempunyai pengertian lebih luas dari pada itu, tetapi definisi di atas memberikan kenyataan bahwa kita terutama mengelola sumberdaya manusia bukan materil atau finansial. Di lain pihak, manajemen mencakup fungsi-fungsi perencanaan (penetapan apa yang akan dilakukan), pengorganisasian (perancangan dan penugasan kelompok kerja), penyusunan personalia (penarikan, seleksi, pengembangan, pemberian kompensasi dan penilaian produktivitas kerja). Manajemen sumber daya manusia menganggap bahwa karyawan adalah kekayaan (asset) utama organisasi yang harus dikelola dengan baik, jadi MSDM sifatnya lebih strategis bagi organisasi dalam mencapai tujuantujuan yang talah ditetapkan. Beberapa pakar MSDM memberikan pandangan yang beragam tentang manajemen SDM.

Rachmawati (2008) memberikan definisi manajemen sumber daya manusia sebagai berikut : Manajemen sumber daya manusia merupakan suatu proses perencanaan, pengorganisasian, pengarahan dan pengawasan kegiatan-kegiatan pengadaan, pengembang-an, pemberian kompensasi, pengintegrasian, pemeliharaan dan pelepasan sumber daya manusia agar tercapai berbagai tujuan individu, organisasi dan masyarakat.

Selanjutnya, Yuniarsih dan Suwatno (2008) mengemukakan bahwa : “ Manajemen sumber daya manusia merupakan bagian dari ilmu manajemen yang memfokuskan perhatiannya pada pengaturan peranan sumber daya manusia dalam kegiatan suatu organisasi“". Hal senada dikemukakan pula oleh Rivai (2009) bahwa : Manajemen sumber daya manusia merupakan salah satu bidang dari manajemen yang meliputi segi-segi perencanaan, pengorganisasian, pelaksanaan dan pengendalian. Karena sumber daya manusia dianggap semakin penting perannya dalam pencapaian tujuan organisasi, maka berbagai pengalaman dan hal penelitian dalam bidang sumber daya manusia dikumpulkan secara sistematis. Istilah manajemen mempunyai arti sebagai kumpulan pengetahuan tentang bagaimana seharusnya mengelola sumber daya manusia.

Fungsi Manajemen Sumber Daya Manusia menurut Malayu S.P. Hasibuan (2012) yaitu : Fungsi Manajerial: (1) Perencanaan (planning) Merencanakan tenaga kerja secara efektif serta efisien agar sesuai dengan kebutuhan perusahaan dalam membantu terwujudnya tujuan.Perencanaan di lakukan dengan menetapkan program kepegawaian; (2) Pengorganisasian (organizing) Kegiatan untuk mengorganisasi semua karyawan dengan menetapkan pembagian kerja, hubungan kerja, delegasi wewenang, integrasi, dan koordinasi dalam bagan organisasi. Organisasi hanya merupakan alat untuk mencapai tujuan, dengan organisasi yang baik akan membantu mewujudkan tujuan secara efektif; (3) Pengarahan (directing) Kegiatan mengarahkan semua karyawan, agar mau bekerja sama dan bekerja efektif serta efisien dalam membantu tercapainya tujuan perusahaan, karyawan dan masyarakat; (4) Pengendalian (controlling) Kegiatan mengendalikan semua karyawan agar mentaati peraturanperaturan perusahaan dan bekerja sesuai dengan rencana. 


\subsection{Pengertian Kinerja}

Kinerja (performance) adalah gambaran mengenai tingkat pencapaian pelaksanaan suatu kegiatan/kebijakan dalam mewujudkan sasaran, tujuan, misi, dan visi organisasi yang tertuang dalam startegic planning suatu organisasi. Istilah kinerja sering digunakan untuk menyebut prestasi atau tingkat keberhasilan individu maupun kelompok individu. Kinerja bisa diketahui hanya jika individu atau kelompok individu tersebut mempunyai kriteria keberhasilan yang telah ditetapkan. Kriteria keberhasilan ini berupa tujuan-tujuan atau targettarget tertentu yang hendak dicapai. Tanpa ada tujuan atau target, kinerja seseorang atau organisasi tidak dapat diketahui karena tidak ada tolak ukurnya (sumber: Mahsun 2006).

Menurut Chaizi Nasucha dalam Sinambela (2012) kinerja organisasi didefinisikan sebagai efektifitas organisasi secara menyeluruh untuk memenuhi kebutuhan yng ditetapkan dari setiap kelompok yang berkenaan melalui usahausaha yang sistematik dan meningkatkan kemampuan organisasi secara terusmenerus untuk mencapai kebutuhannya secara efektif. Wibowo (2011:7) mengatakan bahwa kinerja berasal dari pengertian performance. Ada pula yang memberikan pengertian performance sebagai hasil kerja atau prestasi kerja. Namun, sebenarnya kinerja mempunyai makna yang lebih luas, bukan hanya hasil kerja, tetapi termasuk bagaimana proses pekerjaan berlangsung, Berdasarkan beberapa definisi mengenai kinerja organisasi diatas, dapat ditarik kesimpulan bahwa kinerja organisasi merupakan hasil kerja organisasi ataupun gambaran mengenai apakah suatu organisasi telah dapat melaksanakan kegiatan/kebijakan sesuai dengan visi dan misi yang telah dibuat oleh organisasi.

Dari uraian di atas dapat disimpulkan bahwa pengertian kinerja adalah hasil kerja yang dicapai seseorang karyawan terhadap pelaksanaan tugas pekerjaan yang dinilai berdasarkan pada kriteria atau standar penilaian tertentu. Istilah kinerja sering digunakan untuk menyebut tingkat keberhasilan individu atau kelompok. Sedangkan kinerja bisa diketahui jika individu tersebut mempunyai kriteria keberhasilan yang telah ditetapkan.

\subsection{Pengertian Pemimpin dan Kepemimpinan}

Secara sempit pengertian kepemimpinan menurut Kartono (2005) mengandung arti pemerintah memegang kekuasaan seorang pemimpinan yang dapat mengatur atau mengatur segala sesuatu yang berhubungan dengan organisasi atau instansi yang dipimpinnya demi tercapainya, suatu tujuan tertentu. Menurut House dalam Gary Yukl, (2009) mengatakan bahwa : Kepemimpinan adalah kemampuan individu untuk mempengaruhi, memotivasi, dan membuat orang lain mampu memberikan kontribusinya demi efektivitas dan keberhasilan organisasi. Jadi dari pendapat House dapat dikatakan bahwa kepemimpinan merupakan cara mempengaruhi dan memotivasi orang lain agar orang tersebut mau berkontribusi untuk keberhasilan organisasi.

Adapun dari sisi Atribut, kepemimpinan adalah kumpulan karakteristik yang harus dimiliki oleh seorang pemimpin. Oleh karena itu, dapat dikatakan bahwa kepemimpinan merupakan faktor penentu bagi kehidupan, perkembangan bahkan matinya suatu organiasasi disektor apapun dia bergerak. Pemimpin yang berhasil tidak hanya tergantung dari berapa banyak keterampilan yang ia kuasai, namun juga dapat bergantung pada cara ia berprilaku dan tindakan yang dilakukuannya. 
Berdasarkan definisi kepemimpinan di atas dapat diartikan bahwa kepemimpinan adalah kemampuan seseorang dalam mempengaruhi, menggerakkan, mendorong, mengendalikan orang lain atau bawahannya untuk melakukan sesuatu pekerjaan atas kesadarannya dan berkontribusi dalam mencapai suatu tujuan.

\subsection{Fungsi - fungsi Kepemimpinan}

Kemampuan mengambil keputusan merupakan kriteria utama dalam menilai efektivitas kepemimpinan seseorang. Dalam hubungan ini perlu ditekankan bahwa yang dimaksud dengan kemampuan mengambil keputusan tidak hanya diukur secara kuantitatif, dalam arti jumlah keputusan yang diambil. Tetapi juga diperlukan keputusan yang bersifat praktis, realistis dan dapat dilaksanakan serta memperlancar usaha pencapaian tujuan organisasi. Berkaitan dengan kriteria pengambilan keputusan tersebut.

Menurut Siagian (2008) terdapat 5 (lima) fungsi kepemimpinan sebagai berikut: (1) Pimpinan selaku penentu arah yang akan ditempuh dalam usaha pencapaian tujuan; (2) Wakil dan juru bicara organisasi dalam hubungan dengan pihak - pihak di luar organisasi; (3) Pimpinan selaku komunikator yang efektif; (4) Mediator yang andal, khususnya dalam hubungan secara internal terutama dalam menangani situasi konflik; (5) Pimpinan selaku integrator yang efektif, rasional, objektif dan netral.

Berdasarkan fungsi kepemimpinan yang hakiki dapat diketahui bahwa efektivitas kepemimpinan seseorang berasal dari ciri-ciri kepemimpinan yang dimilikinya dimungkinkan oleh 3 (tiga) sumber (Siagian, 2008) yaitu: (1) Sumber genetika, dalam arti bakat yang dibawa sejak orang dilahirkan; (2) Ciri - ciri yang diperoleh karena belajar dari pengalaman; (3) Ciri-ciri yang diperoleh melalui pendalaman teori kepemimpinan. Yang dikemukakan tersebut merupakan serangkaian ciri-ciri yang bersifat ideal artinya, betapa pun besarnya bakat kepemimpinan yang dimiliki seseorang dan betapa banyak pun kesempatan untuk menempa diri menjadi pemimpin yang efektif melalui pengalaman dan pendidikan serta latihan, tidak ada seorang pun memiliki semua ciri tersebut. Jelasnya, meningkatkan efektivitas kepemimpinan merupakan proses.

\subsection{Pengertian Lingkungan Kerja}

Lingkungan kerja dalam suatu perusahaan sangat penting untuk diperhatikan manajemen. Meskipun lingkungan kerja tidak melaksanakan proses produksi dalam suatu perusahaan, namun lingkungan kerja mempunyai pengaruh langsung terhadap para karyawan yang melaksanakan proses produksi tersebut. Meskipun faktor ini adalah penting dan besar pengaruhnya, akan tetapi masih banyak organisasi yang sampai saat ini kurang memperhatikan lingkungan kerja tempat di mana para karyawannya bekerja.

Karyawan akan mampu mencapai kinerja maksimal apabila memiliki motif berprestasi tinggi. Motif berprestasi yang perlu dimiliki karyawan harus ditumbuhkan dalam diri sendiri yang akan membentuk kekuatan diri dan dari lingkungan kerja yang turut mendukung maka pencapaian kinerja akan lebih mudah. Alex Nitisemito (2009) Lingkungan kerja adalah segala sesuatu yang ada di sekitar pekerjaan dan dapat mempengaruhi seorang karyawan dalam menjalankan tugas-tugas yang dibebankan kepadanya. Sedarmayanti (2012) Lingkungan kerja adalah keseluruhan alat perkakas dan bahan yang dihadapi lingkungan sekitarnya di mana seseorang bekerja, metode kerjanya, serta pengaturan kerjanya baik sebagai perseorangan maupun sebagai kelompok. 
Gouzaly Saydam (2008) Lingkungan kerja adalah keseluruhan sarana dan prasarana kerja yang ada disekitar pegawai yang sedang melakukan pekerjaan yang dapat mempengaruhi pelaksanaan pekerjaan itu sendiri. Schultz dan Schultz (2010) Lingkungan atau kondisi kerja adalah semua aspek fisik kerja, psikologis kerja dan peraturan kerja yang dapat mempengaruhi kepuasan kerja dan produktivitas kerja.

Newstrom (2008) "Work condition relates to the scheduling of work-the length of work days and the time of day (or night) during which people work". yang kurang lebih berarti bahwa kondisi kerja berhubungan dengan penjadwalan dari pekerjaan, lamanya bekerja dalam hari dan dalam waktu sehari atau malam selama orang-orang bekerja. Chandrasekar (2011) dalam International Journal Of Enterprise Computing Business System Lingkungan kerja adalah sekumpulan lingkungan kerja pada suatu tempat berdampak pada semangat pegawai, serta produktivitas baik secara positif maupun negatif.

\subsection{Pengertian Motivasi}

Motivasi adalah "pemberian dorongan-dorongan individu untuk bertindak yang menyebabkan orang tersebut berperilaku dengan cara tertentu yang mengarah pada tujuan" (Imam Ghozali, 2006). Pemeberian motivasi merupakan salah satu tujuan agar karyawan yang diberi motivasi dapat bekerja sesuai dengan acuan kerja dan tanggung jawab yang diberikan sehingga tujuan perusahaan dapat tercapai dengan baik. Selain itu, juga terkandung unur-unsur upaya, yaitu upaya yang berkualitas dan diarahkan serta konsisten dengan tujuan-tujuan organisasi yang ingin dicapai.

Aktifitas manusia sangat ditentukan oleh dorongan, baik dorongan yang datang dari dalam dirinya sendiri maupun dorongan yang datang dari luar. Apabila dorongan tersebut tinggi dan positif, maka hasil dari aktivitasnya akan mendapatkan nilai yang lebih baik. Tetapi sebaliknya, apabila dorongan terebut rendah dan negatif, maka hasilnya akan kurang baik. Dorongan tersebut biasa disebut motivasi.

Istilah motivasi (motivation) berasal dari bahasa latin, yakni movere, yang berarti "menggerakkan" (to move). Motivasi mempengaruhi jenis penyesuaian yang dilakukan oleh karyawan dalam suatu organisasi. Adapun macam-macam rumusan untuk istilah motivasi, seperti yang diungkapkan oleh Mitchell (Winardi, 2008), Motivasi merupakan hal yang mengkaji tentang bagaimana caranya mengarahkan daya potensi bawahan agar mau bekerja secara produktif sehingga dapat mencapai dan mewujudkan tujuan yang telah ditetapkan. Motivasi kerja terdiri dari dua kata, yaitu motivasi dan kerja

Menurut Robbins (2010), mengatakan: Motivasi adalah kesediaan untuk mengeluarkan tingkat upaya yang tinggi untuk tujuan organisasi yang dikondisikan oleh kemampuan upaya itu sendiri dalam memenuhi beberapa kebutuhan individual. Kebutuhan terjadi apabila tidak ada keseimbangan antara apa yang dimiliki dan apa yang diharapkan. Dorongan merupakan kekuatan mental yang berorientasi pada pemenuhan harapan dan pencapaian tujuan. Dan tujuan adalah sasaran atau hal yang ingin dicapai ol eh seorang individu.

\subsection{Hubungan Gaya Kepemimpinan terhadap Kinerja}

Penilaian kinerja merupakan landasan penilaian kegiatan manajemen sumber daya manusia seperti perekrutan, seleksi, penempatan, pelatihan, penggajian, dan pengembangan karir. Kegiatan penilaian kinerja sangat erat kaitannya dengan kelangsungan organisasi. Pemilihan 
gaya kepemimpinan yang benar dan tepat dapat mengarahkan pencapaian tujuan perorangan maupun tujuan perusahaan dan lembaga pemerintahan.

Pengertian Rivai (2014) menyatakan Gaya Kepemimpinan adalah sekumpulan ciri yang digunakan pimpinan untuk memengaruhi bawahan agar sasaran organisasi tercapai atau dapat pula dikatakan bahwa gaya kepemimpinan adalah pola perilaku dan strategi yang disukai dan sering diterapkan oleh seorang pemimpin.Gaya kepemimpinan yang menunjukkan, secara langsung maupun tidak langsung, tentang keyakinan seorang pimpinan terhadap kemampuan bawahannya.

Sehingga dapat disimpulkan bahwa pencerminan seorang pemimpin yang menginspirasi karyawannya akan membantu karyawan tersebut menghasilkan kinerja yang baik. dari sikap yang ditunjukkan oleh seorang pemimpin akan memberikan dorongan bagi karyawan dalam pelaksanaan tugas sehari-hari. Kegiatan kinerja yang ditunjukkan oleh pemimpin menjadi tumpuan yang akan meningkatkan kinerja dari para karyawannya tersebut.

\subsection{Hubungan Lingkungan kerja terhadap Kinerja karyawan}

Didalam penilaian kinerja kesediaan karyawan untuk berpartisipasi dan bekerja sama dengan karyawan lain secara vertikal maupun horizontal didalam maupun diluar pekerjaan sehingga hasil pekerjaan akan semakin baik. Menurut Sedarmayanti (2012) Lingkungan kerja adalah keseluruhan alat perkakas dan bahan yang dihadapi lingkungan sekitarnya di mana seseorang bekerja, metode kerjanya, serta pengaturan kerjanya baik sebagai perseorangan maupun sebagai kelompok. Kesesuaian lingkungan kerja dapat dilihat akibatnya dalam jangka waktu yang lama lebih jauh lagi lingkungan-lingkungan kerja yang kurang baik dapat menuntut tenaga kerja dan waktu yang lebih banyak dan tidak mendukung diperolehnya rancangan sistem kerja yang efisien.

Lingkungan kerja yang menyenangkan bagi karyawan melalui pengikatan hubungan yang harmonis dengan atasan, rekan kerja, maupun bawahan serta didukung oleh sarana dan prasarana yang memadai yang ada di tempat bekerja akan membawa dampak yang positif bagi karyawan, sehingga kinerja karyawan dapat meningkat.

\subsection{Hubungan Motivasi terhadap Kinerja karyawan}

Motivasi terbentuk dari sikap seseorang karyawan dalam menghadapi situasi kerja. Motivasi merupakan kondisi yang menggerakan diri karyawan yang terarah untuk mencapai tujuan organisasi. Menurut Mangkunegara, (2005) berpendapat bahwa ada hubungan positif antara motif berprestasi dengan pencapaian kerja. Motif berprestasi adalah suatu dorongan dalam diri karyawan untuk melakukan suatu kegiatan atau tugas dengan sebaik-baiknya agar mampu mencapai kinerja yang maksimal.

Motivasi dapat dipandang sebagai fungsi, berarti motivasi berfungsi sebagai daya enggerak dari dalam individu untuk melakukan aktivitas tertentu dalam mencapai tujuan. Motivasi dipandang dari segi proses, berarti motivasi dapat dirangsang oleh factor luar, untuk menimbulkan motivasi dalam diri siswa yang melalui proses rangsangan belajar sehingga dapat mencapai tujuan yang di kehendaki. Motivasi dipandang dari segi tujuan, berarti motivasi merupakan sasaran stimulus yang akan dicapai. Jika seorang mempunyai keinginan untuk belajar suatu hal, maka dia akan termotivasi untuk mencapainya. 


\section{Metodologi Penelitian}

Pendekatan penelitian dalam penelitian ini adalah Untuk mengetahui dan menganalisis keadaan yang sebenarnya secara rinci dan aktual dengan melihat masalah dan tujuan penelitian seperti yang telah disampaikan sebelumnya, maka rancangan penelitian akan mengarah pada penggunaan metode kuantitatif. Meski demikian dalam penelitian ini tidak menutup kemungkinan menggunakan cara-cara yang digunakan dalam penelitian kualitatif, selama dalam menggunakan cara-cara tersebut dipandang oleh penulis mampu memaksimalkan dalam pencarian data dan menganalisisnya. Desain penelitian ini adalah kuantitatif yaitu data yang dikumpulkan dengan teknik pengumpulan data yang diperoleh dari hasil penyebaran kuesioner kemudian menggunakan program komputerisasi (SPSS) untuk mendapatkan hasil yang diinginkan.

Populasi merupakan jumlah keseluruhan yang akan menjadi objek penelitian yaitu seluruh pegawai pada PT. Gapura Angkasa di Bandara Internasional Sultan Hasanuddin Makassar dengan jumlah 54 pegawai. Sampel penelitian adalah bagian dari populasi yang diambil sebagai sumber data dan dapat mewakili seluruh populasi. Dari jumlah total populasi 54 orang. Metode yang digunakan dalam penelitian ini adalah metode sensus. Dari jumlah total populasi dijadikan sampel dalam penelitian dikarenakan populasinya tidak terlalu banyak.

\section{Hasil dan Pembahasan}

Penentuan karakteristik responden diperlukan dalam penelitian ini, karena menjadi informasi tentang PT. Gapura Angkasa di Bandara International Sultan Hasanuddin Makassar yang merupakan sampel dalam penelitian ini. Seluruh responden dalam penelitian ini berjumlah 54 responden, dan dianggap respresntative dan layak dalam memberikan informasi yang akurat terhadap pernyataan yang diajukan.

Karakteristik responden adalah gambaran dari keseluruhan populasi yang digunakan sebagai sampel dalam penelitian ini, data ataupun informasi yang diperoleh terkait dengan Gaya kepemimpinan, Lingkungan Kerja dan Motivasi Terhadap Kinerja pada PT. Gapura Angkasa di Bandara International Sultan Hasanuddin Makassar. Berdasarkan hasil penelitian diperoleh data responden mengenai tingkat umur, jenis kelamin, masa kerja dan tingkat pendidikan, yang dapat dijadikan masukan bagi beberapa variabel yang diteliti dalam penelitian ini. Data responden ini diperoleh dari data primer yang dapat dideskripsikan sebagai berikut. Berdasarkan data primer yang dikumpulkan melalui penyebaran kuesioner, diperoleh tingkat umur yang dirangkum dalam tabel dibawah ini:

Tabel 2. Karakteristik Responden Tingkat Umur

\begin{tabular}{|c|c|c|c|}
\hline No & $\begin{array}{c}\text { Umur } \\
\text { (Tahun) }\end{array}$ & $\begin{array}{c}\text { Frekuensi } \\
(\text { F })\end{array}$ & $\begin{array}{c}\text { Persentase } \\
(\%)\end{array}$ \\
\hline 1. & $29-35$ & 13 & 24,07 \\
\hline 2. & $36-40$ & 10 & 18.51 \\
\hline 3. & $41-45$ & 9 & 16.66 \\
\hline 4. & $>46$ & 22 & 40,74 \\
\hline \multicolumn{2}{|c|}{ Jumlah } & 54 & 100 \\
\hline
\end{tabular}

Sumber: Data Primer, 2019 
Tingginya persentase umur pada PT. Gapura Angkasa di Bandara International Sultan Hasanuddin Makassar. mengisyaratkan bahwa pegawai memiliki kematangan intelektual dan emosional sehingga kematangan berfikir. Berdasarkan data primer yang dikumpulkan melalui penyebaran kuesioner, diperoleh profil responden menurut masa kerja yang dirangkum dalam tabel dibawah ini:

Tabel 3. Karakteristik Responden Menurut Masa Kerja

\begin{tabular}{|c|c|c|}
\hline $\begin{array}{c}\text { Masa Kerja } \\
\text { (Tahun) }\end{array}$ & $\begin{array}{c}\text { Frekuensi } \\
(\mathbf{F})\end{array}$ & $\begin{array}{c}\text { Persentase } \\
(\mathbf{\%})\end{array}$ \\
\hline$<5$ & 1 & 1,85 \\
\hline $6-10$ & 16 & 29,63 \\
\hline$>11$ & 37 & 68,52 \\
\hline Jumlah & $\mathbf{5 4}$ & $\mathbf{1 0 0}$ \\
\hline
\end{tabular}

Sumber: Data Primer, 2019

Tingginya persentase masa kerja pada PT. Gapura Angkasa di Bandara International Sultan Hasanuddin Makassar, mengisyaratkan bahwa pegawai relatif sudah lama. Berdasarkan data primer yang dikumpulkan melalui penyebaran kuesioner, diperoleh jenis kelamin yang dirangkum dalam tabel dibawah ini:

Tabel 4. Karakteristik Responden Jenis Kelamin

\begin{tabular}{|c|c|c|}
\hline Jenis Kelamin & $\begin{array}{c}\text { Frekuensi } \\
(\text { F })\end{array}$ & $\begin{array}{c}\text { Persentase } \\
(\%)\end{array}$ \\
\hline Laki-Laki & $\mathbf{3 0}$ & $\mathbf{5 5 . 6}$ \\
\hline Perempuan & $\mathbf{2 4}$ & $\mathbf{4 4 . 4}$ \\
\hline Jumlah & $\mathbf{5 4}$ & $\mathbf{1 0 0}$ \\
\hline
\end{tabular}

Sumber: Data Primer, 2019

Hal ini wajar karena dalam pelaksanaan tugas dan fungsi membutuhkan pegawai laki-laki yang lebih rasional dibandingkan dengan pegawai perempuan. erdasarkan data primer yang dikumpulkan melalui penyebaran kuesioner, diperoleh profil responden menurut tingkat pendidikan yang dirangkum dalam tabel dibawah ini:

Tabel 5. Karkteristik Resonden Menurut Tingkat Pendidikan

\begin{tabular}{|c|c|c|c|}
\hline No & Tingkat Pendidikan & $\begin{array}{c}\text { Frekuensi } \\
(\mathrm{F})\end{array}$ & $\begin{array}{c}\text { Persentase } \\
(\%)\end{array}$ \\
\hline 1. & SMU/SMK & - & - \\
\hline 2 & D3 & 11 & 20.37 \\
\hline 3. & S1 & 41 & 75.92 \\
\hline 4. & S2 & 2 & 3.70 \\
\hline \multicolumn{2}{|c|}{ Jumlah } & $\mathbf{5 4}$ & $\mathbf{1 0 0}$ \\
\hline
\end{tabular}

Sumber: Data Primer, 2019

Hal ini menunjukkan tingkat pendidikan Pegawai pada PT. Gapura Angkasa di Bandara International Sultan Hasanuddin Makassar. mampu dalam menjalankan tugas-tugas yang diberikan sesuai dengan kemampuannya.

Pengujian terhadap hasil regresi yang diperoleh dilakukan pengujian secara serempak dengan menggunakan uji-F dan pengujian secara parsial dengan menggunakan uji-t. Maka dapat diuraikan untuk lebih jelasnya : 
Adapun hasil pengujian secara serempak, dapat dilihat pada tabel berikut ini:

Tabel 6. Pengujian Secara Serempak (Uji-F)

\begin{tabular}{|ll|r|r|r|r|r|}
\hline \multicolumn{2}{|l|}{ Model } & \multicolumn{1}{|c|}{$\begin{array}{c}\text { Sum of } \\
\text { Squares }\end{array}$} & df & Mean Square & F & Sig. \\
\hline 1 & Regression & 8,839 & 3 & 2,946 & 729,263 &, $000^{\mathrm{b}}$ \\
& Residual &, 202 & 50 &, 004 & & \\
Total & 9,041 & 53 & & & \\
\hline
\end{tabular}

a. Dependent Variable: y

b. Predictors: (Constant), x3, x1, x2

Sumber : Output SPSS yang Diolah, 2017

Hal ini dapat ditarik kesimpulan bahwa secara serempak variabel Gaya Kepemimpinan, Lingkungan Kerja dan motivasi berpengaruh signifikan dan positif terhadap kinerja pegawai pada PT.Gapura Angkasa di Bandara International Sultan Hasanuddin Makassar.

Hasil pengujiannya dapat dilihat dari nilai t-hitungnya. Adapun hasil pengujian secara parsi (t-hitung) maka dapat dilihat dari tabel dibawah ini :

Tabel 7. Pengujian Secara Parsial (Uji-t)

\begin{tabular}{|l|c|c|c|}
\hline \multicolumn{1}{|c|}{ Variabel Independent } & $\begin{array}{c}\text { Koefisien } \\
\text { Regresi (B) }\end{array}$ & t- hitung & Sig \\
\hline Gaya kepemimpinan (X1) & 0.419 & 8,519 & 0,000 \\
Lingkungan Kerja (X2) & 0.155 & 2,997 & 0,004 \\
Motivasi (X3) & 0,449 & 7,537 & 0,000 \\
\hline \multicolumn{2}{|r|}{ Konsatanta (b) $)$} & 0.033 \\
\hline
\end{tabular}

Hal ini dapat diketahui dari nilai t-hitung yang diperoleh lebih besar dari t-tabel atau t-hitung lebih kecil dari t-tabel. Hasil analisis juga menunjukkan dari kedua variabel yang berpengaruh, ternyata variabel motivasi mempunyai pengaruh dominan dalam meningkatkan kinerja pegawai pada PT.Gapura Angkasa di Bandara International Sultan Hasanuddin Makassar.

Besarnya kontribusi yang diberikan dari variabel Gaya Kepemimpinan, Ligkungan Kerja dan motivasi terhadap Kinerja pada PT.Gapura Angkasa di Bandara International Sultan Hasanuddin Makassar dan dapat dilihat dari koefisien determinasinya. Perolehan nilai determinasi $\left(\mathrm{R}^{2}\right)$ dapat dilihat pada tabel dibawah ini :

Tabel 8. Hasil pengujian Koefisien Determinasi $\left(\mathrm{R}^{2}\right)$

\begin{tabular}{|c|c|c|c|}
\hline \multirow{2}{*}{ Model } & $\mathrm{R}$ & $\mathrm{R}$ Square & \\
\hline 1 & $0.989^{\circledR}$ & 0.978 & Adjusted R Square \\
\hline
\end{tabular}

Sumber: Output SPSS yang diolah, 2019 
Berdasarkan hasil uji determinasi tabel tersebut diatas, maka dapat dijelaskan bahwa besarnya koefisien determinasi $\left(\mathrm{R}^{2}\right)$ adalah 0.978. Angka koefisien determinasi menyatakan bahwa variabel Gaya Kepemimpinan, Lingkungan Kerja dan Motivasi hanya dapat menjelaskan atau memberikan kontribusi atas variasi perubahan kinerja pegawai sebesar 97.8\%. Sedangkan sisanya sebesar $2.2 \%$ dipengaruhi oleh variabel-variabel lain yang tidak dilibatkan dalam penelitian ini.

Gaya kepemimpinan adalah ciri atau tipe perilaku yang digambarkan oleh seorang pemimpin dalam memimpin bawahannya untuk mencapai suatu tujuan tertentu dan merupakan faktor yang tidak bisa dipisahkan dari seorang pemimpin. Di dukung adanya lingkungan kerja yang kondusif akan menciptakan kinerja yang optimal. Dari tabulasi jawaban responden memperlihatkan bahwa dari keempat indikator pada variabel gaya kepemimpinan $\left(X_{1}\right)$ dengan frekuensi tertinggi yakni pada indikator 4 sebanyak 45 responden dengan besar persentasenya 83,3 persen pada indikator 4 mengenai Pemimpin yang menghargai dan memuji para pegawai dan memberikan penghargaan bagi pegawai yang hasil kerjanya bagus, maka akan berdampak pada peningkatan kinerja pegawai tersebut dan jawaban responden yang tertinggi kedua adalah pada indikatir ke 3 sebesar 37 responden atau 68,5 persen yaitu Pemimpin anda menetapkan tujuan-tujuan dan memberikan perintah-perintah setelah hal-hal itu didiskusikan terlebih dahulu dengan bawahan.

Nitisemito (2002) mengemukakan "Lingkungan kerja adalah segala yang ada disekitar para pekerja yang dapat mempengaruhi dirinya dalam menjalankan tugas-tugas yang dibebankan". Lingkungan kerja adalah tempat dimana para pegawai melakukan tugas dan segala aktivitas dan kewajibanya dalam suatu pekerjaan. Lingkungan kerja yang kondusif baik lingkungan kerja fisik maupun lingkungan kerja non fisik mampu mempengaruhi semangat serta motivasi kerja karyawan sehingga mereka mampu bekerja dengan optimal. Dari tabulasi jawaban responden memperlihatkan memperlihatkan bahwa dari ke 5 indikator pada variabel likungan kerja $\left(\mathrm{X}_{2}\right)$ dengan frekuensi tertinggi yakni sebanyak 45 responden dengan besar persentasenya 83,3 persen pada indikator 3 mengenai Sistem pemberian imbalan (baik gaji maupun perangsang lain) yang menarik maka akan berdampak pada peningkatan kinerja pegawai tersebut dan jawaban responden yang tertinggi kedua adalah pada indikatir ke 2 sebesar 37 responden atau 68,5 persen yaitu Suasana kerja yang dapat memberikan dorongan semangat kerja yang tinggi mampu meningkatan kerja pegawai.

Motivasi adalah serangkaian sikap dan nilai-nilai yang mempengaruhi individu untuk mencapai hal yang spesifik sesuai dengan tujuan individu. Sikap dan nilai tersebut merupakan suatu kekuatan untuk mendorong individu bertingkah laku dalam mencapai tujuan. Dorongan tersebut terdiri dari dua komponen, yaitu: arah perilaku kerja (kerja untuk mencapai tujuan), dan kekuatan perilaku (sebagai kuat usaha individu dalam bekerja). Hal ini dapat terlihat pada rekapitulasi jawaban Dari hasil dari ke 4 indikator pada variabel motivasi $\left(\mathrm{X}_{3}\right.$ ) dengan frekuensi tertinggi yakni sebanyak 45 responden dengan besar persentasenya 83,3 persen pada indikator 3 menjalin hubungan kerjasama yang baik kepada semua karyawan dan pimpinan akan memotivasi untuk bekerja maka akan berdampak pada peningkatan kinerja pegawai tersebut dan jawaban responden yang tertinggi kedua adalah pada indikatir ke 2 sebesar 37 responden atau 68,5 persen yaitu merasakan aman saat menjalankan pekerjaan mampu memotivasi kerja pegawai. 
Penelitian yang dilakukan oleh fricilia runtuwene dengan judul "pengaruh motivasi kerja terhadap kinerja pegawai di badan kepegawaian daerah kabupaten minahasa selatan" Dalam kinerja ada beberapa hal yang harus diperhatikan yaitu kualitas, kuantitas, dan ketepatan waktu. Diperlukan dorongan yang kuat untuk memenuhi indikator kinerja tersebut agar mencapai hasil yang baik. Dorongan-dorongan disini merupakan motivasi kerja yang harus dimiliki oleh setiap pegawai. Tujuan Penelitian ini adalah untuk mengetahui pengaruh motivasi kerja dengan kinerja pegawai di Badan Kepegawaian Daerah Kabupaten Minahasa Selatan. Pendekatan penelitian yang digunakan adalah kuantitatif deskriptif dan didukung dengan data sekunder. Jenis data yang digunakan adalah data primer diperoleh dari hasil pengolahan data kuesioner dan data sekunder diperoleh dari pengolahan data dan observasi. Teknik analisis data dimulai dari penyebaran kuesioner kepada responden, kemudian pengolahan data dengan uji validitas, uji reliabilitas, Uji Korelasi Product Moment, kemudian Uji Signifikansi Koefisien Regresi Sederhana (Uji t), dan terakhir menarik kesimpulan. Berdasarkan uji korelasi antara motivasi kerja dengan kinerja pegawai, terbukti ada hubungan yang kurang signifikan antara motivasi kerja dengan kinerja pegawai. Hal ini dapat dibuktikan pada persamaan korelasi yang memberikan hasil koefisien korelasi (r) sebesar 0,274 . Tanda positif (+) yang diperlihatkan dari koefisien korelasi (r) menunjukkan bahwa meskipun tingkat korelasinya rendah, namun berhubungan positif yang artinya jika variable motivasi kerja meningkat, maka akan diikuti oleh variabel kinerja pegawai dan sebaliknya oleh variabel kinerja pegawai dan sebaliknya.

\section{Simpulan}

Berdasarkan hasil penelitian dan pembahasan maka dapat disimpulkan sebagai berikut: (1) Hasil pengujian hipotesis membuktikan bahwa gaya kepemimpinan memiliki pengaruh positif dan signifikan terhadap peningkatan kinerja pegawai pada PT.Gapura Angkasa di Bandara International Sultan Hasanuddin Makassar. Mempunyai arti positif yang menunjukkan bahwa gaya kepemimpinan berpengaruh positif terhadap kinerja pegawai pada PT.Gapura Angkasa di Bandara International Sultan Hasanuddin Makassar. Dapat dijelaskan bahwa apabila dengan adanya peningkatan gaya kepemimpinan dan variabel lainnya konstan, maka akan meningkatkan kinerja pegawai pada PT.Gapura Angkasa di Bandara International Sultan Hasanuddin Makassar; (2) Hasil pengujian hipotesis membuktikan bahwa lingkungan kerja memiliki pengaruh positif dan signifikan terhadap peningkatan kinerja pegawai pada PT.Gapura Angkasa di Bandara International Sultan Hasanuddin Makassar. Memiliki tanda positif yang menunjukkan bahwa lingkungan kerja berpengaruh positif terhadap kinerja pegawai pada PT.Gapura Angkasa di Bandara International Sultan Hasanuddin Makassar. Hal tersebut dapat dijelaskan apabila terjadi peningkatan lingkungan kerja dan variabel bebas lainnya konstan, maka akan meningkatkan kinerja pegawai pada PT.Gapura Angkasa di Bandara International Sultan Hasanuddin Makassar; (3) Hasil pengujian hipotesis membuktikan bahwa motivasi memiliki pengaruh positif dan signifikan terhadap peningkatan kinerja pegawai pada PT.Gapura Angkasa di Bandara International Sultan Hasanuddin Makassar. Memiliki tanda positif yang menunjukkan bahwa motivasi berpengaruh positif terhadap kinerja pegawai pada PT.Gapura Angkasa di Bandara International Sultan Hasanuddin Makassar. Hal tersebut dapat dijelaskan apabila terjadi peningkatan motivasi dan variabel bebas lainnya konstan, maka akan meningkatkan kinerja pegawai pada PT.Gapura Angkasa di Bandara International Sultan Hasanuddin Makassar; (4) Kontribusi Gaya kepemimpinan, lingkungan kerja dan motivasi terhadap Kinerja pegawai pada PT.Gapura Angkasa di Bandara International Sultan Hasanuddin Makassar. 
Disarankan untuk (1) kepada pimpinan agar dapat menghargai, memuji dan memberikan penghargaan bagi pegawai yang hasil kerjanya bagus serta menetapkan tujuan, memberikan perintah setelah hal-hal itu didiskusikan terlebih dahulu dengan bawahan ternyata mampu meningkatkan kinerja pegawai pada PT. Gapura Angkasa di Bandara International Sultan Hasanuddin Makassar; (2) sistem pemberian imbalan (baik gaji maupun perangsang lain) yang menarik serta membuat suasana kerja yang lebih nyaman, komunikasi yang baik dengan rekan kerja dapat memberikan dorongan semangat kerja yang tinggi sehingga mampu meningkatan kinerja pegawai pada PT. Gapura Angkasa di Bandara International Sultan Hasanuddin Makassar; (3) menjalin hubungan kerjasama yang baik kepada semua karyawan dan pimpinan akan memotivasi untuk bekerja serta merasakan aman saat menjalankan pekerjaan mampu memotivasi kerja sehingga mampu meningkatkan kinerja pegawai pada PT. Gapura Angkasa di Bandara International Sultan Hasanuddin Makassar.

\section{Daftar Pustaka}

Alex, S Nitisemito. (2008). Manajemen Personalia, Ghalia Indonesia, Jakarta.

Alex. S. Nitisemito. (2009). Manajemen Personalia. Edisi Revisi, Penerbit Ghalia Indonesia

Armstrong, Michael. (2009). Armstrong's Handbook of Human Resource Management Practice. Kogan Page: United Kingdom.

Chandrashekar, KN., Muralidhara. (2009) Evidence of oxidative stress andmitochondrial dysfunctions in the testis of prepubertal diabetic rats. [Int J Impot Res] 2009 May-Jun; Vol. 21 (3), pp. 198-206

Dessler, Gary. (2006). Manajemen Sumber Daya Manusia. PT. Indeks : Jakarta

Fuad, Mas'ud. (2004). Survei Diagnosis Organisasional (Konsep dan Aplikasi). Penerbit Universitas Diponegoro.

Dessler, Gary. (2009). Manajemen SDM buku 1. Jakarta : Indeks

Gouzali Saydam. (2008). Manajemen Sumber Daya Manusia Jilid I, Gunung Agung, Jakarta.

Ghozali, Imam. (2006). Aplikasi Analisis Multivatiate dengan Program SPSS, Badan Penerbit Universitas Diponegoro, Semarang.

Cardoso Gomes, Faustino. (2008), Manajemen Sumber Daya Manusia, edisi pertama, cetakan keempat, Andi Offset, Jakarta.

Hasibuan, Malayu. (2010). Manajemen Sumber Daya Manusia, Bumi Aksara, Jakarta

Hasibuan, Malayu. (2012). Manajemen Sumber Daya Manusia, Bumi Aksara, Jakarta

Harbani, Pasolong. (2013).Kepemimpinan Birokrasi. Bandung : CV.Alfabeta.

Luthans, Fred. (2006). Perilaku Organisasi. Alih Bahasa V.A Yuwono, dkk. Edisi Bahasa Indonesia. Yogyakarta: Andi.

Mangkunegara. (2010). Manajemen Sumberdaya Manusia pada Perusahaan. Bandung:PT. Remaja Rosakarya.

Mangkunegara. (2005). Evaluasi Kinerja SDM. PT. Refika Aditama: Bandung.

Marwansyah. (2010). Manajemen Sumber Daya Manusia, Edisi Kedua. Alfabeta : Bandung.

Mashrukin dan Waridin. (2006). Pengaruh Motivasi Kerja, Budaya Kerja, Budaya Organisasi dan Kepemimpinan Terhadap Kinerja Pegawai. EKOBIS Vol. 7 No. 2

Mahsun Mohammad. (2006). Penelitian Bahasa: Berbagai Tahapan Strategi, Metode, dan Teknik-Tekniknya. Mataram: Dirjend Dikti.

Nawawi, Hadari. (2006). Kepemimpinan Mengefektifkan Organisasi, Jogjakarta; Gadjah Mada University Press.

Schultz, D., \& Schultz, E. S. (2010). Psychology and work today (10 edition). New York: Pearson 
Okky Setiawan (2009) dengan judul penelitian "Pengaruh Pelatihan, Kompensasi dan Motivasi Kerja Terhadap Kinerja Karyawan Bagian Industri Pemasaran di Perum Perhutani Unit I Jawa Tengah".

Rivai, Veithzal. (2005). Kepemimpinan Dan Perilaku Organisasi, PT. Raja Grafindo Persada : Jakarta

Rivai, Veithzal dan Ella Jauvani Sagala. (2009). Manajemen Sumber Daya Manusia untuk Perusahaan. Edisi Kedua, Raja Grafindo Persada, Jakarta.

Robbins, Stephen. (2006). Perilaku Organisasi, Indeks, Jakarta

Robbins. Stephen. P dan Coulther Mary. (2010). Manajemen. Edisi kesepuluh. Jakarta. Erlangga

Sedarmayanti. (2012). Manajemen dan Komponen Terkait Lainnya. Bandung: PT. Refika Aditama

Sinambela, Poltak. Lijan. (2012). Kinerja Pegawai Teori Pengukuran dan Implikasi. Yogyakarta: Graha Ilmu.

Sutikno, M. S. (2014). Metode dan Model-Model Pembelajaran: Menjadikan Proses Pembelajaran Lebih Variatif, Aktif, Inovatif, efektif, dan menyenangkan. Mataram: Holistica

Siagian, Sondang P. (2008). Manajemen Sumber Daya Manusia. Jakarta: Penerbit Bumi Aksara

Siswanto. (2006). Pencairan DanaKompensasi di Bekasi RawanKeributan, dalam http://www.tempointeraktif.com/, Selasa 18 Oktober 2009.

Suwatno. (2011). Manajemen Sumber Daya Manusia Dalam Organisasi Publik Dan Bisnis. Bandung Penerbit : Alfabeta

Sukmawati. (2008) dengan judul Pengaruh Pendidikan dan Pelatihan, Pemberdayaan Sumberdaya Manusia, Motivasi, Komunikasi dan Pengalaman Kerja terhadap Kinerja Karyawan Sekertariat Dewan Perwakilan Rakyat Daerah Kabupaten Wonogiri.

Sukmawati. (2009). Manajemen Kepegawaian Sipil di Indonesia. Kencana: Jakarta.

Sukmawati. (2008). Penilaian Kinerja. PT. Raja Grafindo Persada: Jakarta.

Veithzal Rivai dan Ella Jauvani S. (2009). Manajemen Sumberdaya Manusia untuk Perusahaan: Dari Teori ke Praktik. PT Rajagrafindo Persada: Jakarta.

Wibowo. (2010). Budaya Organisasi: Sebuah Kebutuhan Untuk Meningkatkan Kinerja Jangka Panjang. Rajawali Pers PT Raja Grafindo Persada: Jakarta

Wibowo. (2011). Manajemen Kinerja. Rajagrafindo Persada, Jakarta.

Yuniarsih, Tjutju dan Suwatno. (2008). Manajemen Sumber Daya Manusia: Teori, Aplikasi dan Isu Penelitian. CV Alfabeta: Bandung.

Vendy Aries Martcahyo (2010) dengan judul penelitian "Pengaruh Pelatihan Kerja, Jaminan Sosial Dan Insentif Terhadap Kinerja Karyawan Bagian Produksi PT. Fumira Semarang".

\section{Acknowledgement}

Penelitian ini didukung oleh kampus STIE NOBEL Makassar. Kami berterima kasih kepada rekan-rekan kami seluruh karyawan PT. Gapura Angkasa Makassar yang memberikan wawasan dan keahlian yang sangat membantu penelitian, meskipun interpretasi yang kurang berkenan dari berbagai pihak yang ada dalam makalah ini.

\section{Copyright Disclaimer}

Copyright for this article is retained by the author(s), with first publication rights granted to the journal. 